University of Wollongong

Research Online

Faculty of Law, Humanities and the Arts Papers (Archive)

Faculty of Arts, Social Sciences \& Humanities

$1-1-2013$

Precarious work, neoliberalism and young people's experiences of employment in the Illawarra region

Scott Burrows

University of Wollongong, sburrows@uow.edu.au

Follow this and additional works at: https://ro.uow.edu.au/lhapapers

Part of the Arts and Humanities Commons, and the Law Commons

Research Online is the open access institutional repository for the University of Wollongong. For further information contact the UOW Library: research-pubs@uow.edu.au 


\title{
Precarious work, neoliberalism and young people's experiences of employment in the Illawarra region
}

\author{
Abstract \\ Understanding young people's employment experiences and transitions gives a greater appreciation of \\ the nature of precarious work. Drawing on interview data with 30 participants from research conducted in \\ 2011-2012, this article examines young people's experiences of employment in the Illawarra region of \\ New South Wales, Australia. Levels of unemployment and under-employment above the national average \\ reflect two decades of globalised restructuring of the steel, coal and manufacturing industries which, \\ together with agriculture, have historically been the region's economic base. The growth of service and \\ knowledge industries has been accompanied by new, 'atypical' or insecure work patterns. The interview \\ data indicate that young people's diverse experiences of transition and choice in leaving school, \\ commencing training or further education, and entering the labour market are accompanied by a range of \\ understandings of employment and precarious work. These experiences highlight the difficulties, \\ divisions and contradictions in a changing regional labour market and suggest how the ideologies and \\ practices of neo-liberalism shape and are embedded in regional labour markets and precarious work \\ more generally.
}

\section{Keywords}

region, precarious, work, neo, young, illawarra, people, employment, experiences, liberalism

\section{Disciplines}

Arts and Humanities | Law

\section{Publication Details}

Burrows, S. (2013). Precarious work, neoliberalism and young people's experiences of employment in the Illawarra region. The Economic and Labour Relations Review, 24 (3), 380-396. 


\title{
Precarious Work, Neoliberalism and \\ Young People's Experiences of Employment in the Illawarra Region
}

\section{Scott Burrows}

University of Wollongong

\begin{abstract}
Understanding young people's employment experiences and transitions gives a greater appreciation of the nature of precarious work. Drawing on interview data with thirty participants from research conducted in 2011-2012, this article examines young people's experiences of employment in the Illawarra region of New South Wales, Australia. Levels of unemployment and underemployment above the national average reflect two decades of globalised restructuring of the steel, coal and manufacturing industries which, together with agriculture, have historically been the region's economic base. The growth of service and knowledge industries has been accompanied by new, 'atypical' or insecure work patterns. The interview data indicate that young people's diverse experiences of transition and choice in leaving school, commencing training or further education and entering the labour market are accompanied by a range of understandings of employment and precarious work. These experiences highlight the difficulties, divisions and contradictions in a changing regional labour market and suggest how the ideologies and practices of neoliberalism shape and are embedded in regional labour markets and precarious work more generally.
\end{abstract}

\section{Keywords}

Employment, Illawarra region, neoliberalism, precarious work, unemployment, young people

\section{JEL Codes}

z13

University of Wollongong, Northfields Avenue Wollongong New South Wales 2522.

Email contact: sburrows@uow.edu.au

\section{Introduction}

Guy Standing (2011: 13-14) explains the difficulties in defining precarious work:

...however one defines it, the precariat is far from being homogeneous. The teenager who flits in and out of the internet café while surviving on fleeting jobs is not the same as the migrant who uses his wits to survive, networking feverishly while worrying about the police. Neither is similar to the single mother fretting where the money for next week's food bill is coming from or the man in his 60's who takes casual jobs to help pay 
medical bills. But they all share a sense that their labour is instrumental (to live), opportunistic (taking what comes) and precarious (insecure).

There is no one all-encompassing definition of precarious work (Vosko, 2006). Specifically, the term is used to describe particular work arrangements and conditions associated with poor wages, temporary and fixed term contracts and irregular hours (Kalleberg, 2000; 2009; Masterman-Smith and Pocock, 2008; Quinlan, 2012). More generally it includes not only paid employment but the interface of the economy and the welfare state (Vosko 2000). Difficulties in defining the nature and degree of precariousness in young people's employment have been identified in the national and international literature. McKay et al. (2012) for example, identifies four: dimensions of precarious work: (1) job insecurity, whether through short contract duration or through unpredictability of hours; (2) low pay or lack of opportunity to improve it; (3) 'sub-ordinate' employment, leading to exclusion from social, welfare or employment rights; and (4) absence of coverage by collective bargaining or union representation.

However, for many young people aged 15-24 years, deliberately chosen parttime work may not be experienced as precarious, even if there is a desire for more hours of work, stable employment arrangements and fixed or ongoing contracts. Horizons of choice cannot be separated from specific experiences of the labour market. For example, part-time or full-time work can be uncertain and precarious for many young people but the flexibility of such jobs may make their acceptability unquestioned, if they are seen (accurately or not) as potentially improving future job prospects.

Given the shaping of subjectivity by context, this article is a case study of how young people experience their relationship to a particular regional labour market. It shows how changes in local employment options, in a former steel and coal heartland subject to global market pressures, may be experienced in a way that is consonant with neoliberal ideology. Precariousness is normalised as individual choice; insecurity is seen as an inevitable trade-off for the flexibility that workers need in deciding how, when and where they work. The benefits of such flexibility include greater worker control of day to day schedules, greater productivity, better work and family life balance and greater personal and family well-being (Pocock, 2003). The distinction between precarious and 'standard' employment practices has blurred, as a result of 'spill over' effects, whereby stable ongoing jobs are also increasingly exposed to economic contractions or deliberate restructuring informed by competitive market ideologies (Cheshire and Lawrence, 2005). Industry and occupational shifts mean that young people's vocational 'choices' include a further form of precarious work - self-employment in a wide range of blue and white collar work. The decline of heavy manufacturing and mining employment and the diversification of service industries has meant the rise of a 'petty bourgeoisie' that includes artisans, shopkeepers and tradespeople as well as accountants, doctors and lawyers (Gramsci, 1971). Small business and other self-employed proprietors can also be considered part of the growing groups of workers who are becoming precarious (Standing, 2011). The very concept of security, it is now clear, is tied to a standard employment relationship that developed after world war two, and applied mainly to male workers in a narrow range of core industrial sectors (Vosko, 2000).

Attempts to understand and define precarious work are further complicated by how such practices are embedded in the division of labour. A useful approach is examining how neoliberalism, as a set of distinct economic, ideological, political and social practices has developed, informed and defined precarious work in the last few 
decades. The article presents some views of young people about their present work and its relationship to their hoped-for future careers. It shows the prevalence of the individualistic notion that we are all captains of our own destiny - a notion that predates neoliberalism but is fundamental to it. It argues that this is both a way of coming to terms with the limitations of present jobs, but also likely to result in the disappointment of unrealistic expectations.

Despite the individualism that characterises neoliberalism, the Illawarra region has a history of collective responses to youth employment disadvantage. This was shown most starkly during the 1980's when the Wollongong Out of Worker's Union (WOW) was formed in response to mass unemployment (Southall, 2008). In contrast, the focus of this article is on the Illawarra region of New South Wales, Australia where the contemporary youth labour market is strongly characterised by precarious work. With a population of approximately 413,000, and a workforce of 185,000 , the Illawarra includes the city of Wollongong (the third largest city in New South Wales), the deep harbour of Port Kembla, the new growth area of Shellharbour, and a surrounding agricultural region (IRIS Research, 2013). Since the early 1980s, the region has borne the brunt of steel, coal and manufacturing industry restructuring. With the rise of neoliberal policies in the 1970s, the local economy was opened to global market forces and in the period 1980-1983, steel operations were rationalised and local coal mines closed. Retrenchments, voluntary redundancies and their flow-on impacts in other sectors meant that by 1983, unemployment rates in the Illawarra had soared to $33 \%$, with massive social and psychological effects on local communities (Mangan and Guest, 1983; Shultz, 1985; Burrows, 2010a; 2011/2012). During the 1980s and early 1990s, a Steel Industry Plan and a Steel Industry Development Agreement prevented further wholesale retrenchments, in exchange for openness to the discipline of global markets. In the 1990s, world economic trends lowered prices and workers were displaced by technology such as continuous long-wall mining machinery (Kelly 1989; Burrows, 2010a: 27-28). Employment in traditional manufacturing declined and became increasingly polarised between secure and insecure jobs, along sub-contracting supply chains (Mylett, 2003). Most recently, in 2011, the region's BlueScope Steel (still the region's largest employer), announced yet another restructure involving the loss of 700 jobs. The flow-on effects were also a further 100 retrenchments and approximately 350 job losses from regional suppliers and contractors, particularly the new dormitory settlement of Shellharbour (Australian Government, 2012: 15).

Between 1976 and 2006, census data indicate that the percentage of employed persons in the Illawarra who were working in production-based industries fell from $55 \%$ to $24 \%$, while the percentage working in service-based industries rose concomitantly from $45 \%$ to $76 \%$ (Burrows, 2010a: 29). Nevertheless, there continued to be a reliance above the national average on a manufacturing sector that was not growing. The heavy impact of the Global Financial Crisis beginning in 2008 was temporarily mitigated by a government economic stimulus package, which helped fund initiatives that were part of a considered local diversification strategy designed to lay the foundations for a future 'green economy' (Green Jobs Illawarra Action Plan, 2009).

The potential for diversifying the economic base in the Illawarra has been described in optimistic terms:

As more people move out of the workforce and into retirement there will be increased pressure on the region but also opportunities to develop a skilled 
and job ready workforce in areas such as aged care facilities, recreation, retail and health and medical services (Australian Government, 2012: 9)

Major workforce restructuring and economic diversification over the past few decades have resulted in strong growth in the tertiary sector. High levels of growth have been experienced in the retailing, tourism, education and finance industries. As the economic base of the region has changed, a concerted effort has been maintained to match education and training with the needs of employers and new industries. The result is an increasing pool of professional and specialist expertise throughout the region (IRIS Research, 2013).

There are however limits to supply-side solutions, focusing on matching young people to aspirational jobs. A review of recent longitudinal studies of the transitions of school leavers in the Illawarra indicates that, particularly for young men, the best way of avoiding unemployment is rapid access to full-time work. Minimising the severity of youth unemployment requires a demand-side focus on full-time job creation (Burrows, 2010b: 90-94). Yet in 2011, the main sources of employment in the Illawarra were Retail Trade (12.9\%), Education and Training (11.4\%), Manufacturing (11.1\%), Construction (9.6\%), and Accommodation and Food Services (9.0\%) (IRIS Research, 2013). This suggests occupational polarisation, with high concentrations of available jobs in the retail and hospitality sectors, where part time and casual employment prevail. For this reason, the notion of precarious work has become synonymous with the contemporary youth labour market.

The article is organised as follows. The first section positions an understanding of precarious work in the neoliberal era by examining how the ideology of neoliberalism has informed and become embedded in the various transformations occurring in the contemporary youth labour market. The second section outlines the dimensions of youth employment in the Illawarra region, offering an overview of the challenges of the region's precarious youth labour market. The third section outlines the methods and findings of a qualitative research project undertaken in 2011-2012 in order to explore young people's experiences of precarious employment. The article concludes by suggesting areas for further research and the possible trajectories of these research agendas.

\section{Positioning precarious work in the neoliberal era}

The acceleration of precarious work has occurred in an era of globalisation, in which.neoliberalism has become a hegemonic ideology within western societies and has exercised a major influence in the area of employment (Harvey, 2005). It involves the belief allowing markets to operate with as few impediments as possible, even while for the market to reach its full potential, the State has to be active in creating and sustaining the institutions which make that possible (Gamble, 2006: 2122; Robison, 2006: 3). In Australia, governments at all levels have endorsed the ideology while attempting to alleviate chronic unemployment (Stilwell, 2000; Considine, 2001; Carney and Ramia, 2002; Cook et al., 2008).

Peck and Tickell (2002: 381-382) analyse how neoliberal ideas, 'proselytising the virtues of free trade, flexible labor, and active individualism', have become 'selfactualising', representing the market as a 'state of nature', and aligning the local and the global with the 'primary contours of contemporary political-economic power'. The Illawarra industry restructuring of the 1970s and 1980s corresponds to what Peck and Tickell (2002) define as neoliberalism's first, 'roll-back' phase, characterised by the weakening of the Keynesian state and collectivist institutions such as unions. 
This did not occur without strenuous efforts at community mobilisation and job creation by the South Coast Labour Council, historically an important focus of local solidarity (Rittau, 2006).

In Peck and Tickell's typology, 'roll-back' neoliberalism reaches its own limits, with manifest market failure and adverse social consequences resulting in a second 'roll-out phase, based on neoliberal forms of regulation and governance. One aspect of the roll-out has been the encouragement of 'urban entrepreneurialism', based on zero-sum competition amongst cities to attract increasingly mobile capital and government funding (pp. 385-386). In this phase, local economic development becomes the first priority, with social welfare seen as something that must wait for, or depend on, growth and the attraction of investment. At all policy levels, competition becomes the rationale for reconstituting labour markets in a way that create 'regimes of precarious work' and' mobilize the poor for low-wage employment', through discourses of eradicating 'welfare dependency' (pp. 386-7). This agenda is followed, lest a region be left behind in the competition for resources (p. 394). Indeed Australian commentators have argued that, lacking the power to generate ongoing employment, regional development bodies are themselves likely to become products and victims of neoliberalism - agencies without the resources to effect the solutions devolved to them by state and federal governments (Beer, et al., 2005). This has been less the case in the Illawarra, where recent initiatives such as the Green Jobs Action Plan (2009) have been developed by community coalitions. Nevertheless, the young people in the case study discussed in this article seemed to be aware of few resources beyond their own initiative in navigating the world of work.

Dimensions of neoliberalism have shaped the contemporary youth labour market in the Illawarra, as in Australia more generally. The need for labour market flexibility is closely associated with precarious work. Labour market deregulation lowers labour costs in a bid to prevent capital from transferring production costs to areas and countries where costs are more competitive (Standing, 2011: 6). Indeed, flexibility has become a central factor in the rise of precarious work, as social protection in the form of organised labour and the welfare state has effectively been weakened. At the same time, the precariousness of the labour market has increased significantly with 'over one in four Australian workers now in casual employment' (Masterman-Smith and Pocock, 2008: 205). Evidence from a recent study on insecure work found that casual employment has become the norm for over two million Australians with the greatest and most rapid growth occurring in casual fulltime and part-time jobs (Rafferty and Yu, 2010: 6).

Focusing on young people and their experiences of precarious work, Eardley (2000: 15) noted more than a decade ago the incidence of low pay. For example, in the decade from the mid 1980's to the mid 1990's, low pay was experienced by more than half of employees under 21 when compared to the rest of the labour force. The social impacts of such trends,

including high levels of anxiety and uncertainty, remain one of the key findings in this and other research that has explored precarious work (van Wanrooy 2009). The basic components of the post-war wage structure including guaranteed sick and holiday leave has slowly been eroded and the capacity of these workers to have time off for themselves and their families is disappearing. It also raises more serious questions concerning broader economic and social participation such as adequate housing, income, job security, levels of superannuation and taxation (particularly on second and third jobs) and the interface between welfare and work (Watson et al., 2003). 
For the reasons outlined above, employment policies that appropriately deal with precarious work are generally limited and ineffective while the link to poverty and other forms of inequality is likely to continue rather than recede. The possibility of de-coupling neoliberal ideology from its fragmented practices also remains unclear. This is despite the brief injection of stimulus spending into the Australian economy during 2008-2009. As Humphrys and Collerson (2012/2013: 6) note, there is an ongoing likelihood of:

Low taxation of industry, cuts to welfare and the social wage, continued privatisation of public assets, further private sector losses underwritten by the public purse, and attempts to suppress wages below inflation and to force the end of long-held workplace conditions. In this context, it is timely to examine the nature and dimensions of precarious work in the Illawarra region. Specifically, this area provides a useful snapshot exposing how various young workers experience precarious work and highlights how the region's economy and broader labour market have been restructured. The focus of young people and their employment experiences (whether in work or not) has a particular importance because it develops a greater appreciation of how ideologies such as neoliberalism have transformed the employment conditions in this region.

\section{The Context of Youth Employment in the Illawarra Region}

The political economic and sociological research on young peoples' employment experiences in regional labour markets in Australia and overseas has been substantial in the last two decades (see Wooden, 1996; Lewis and McLean, 1998; Kelly and Lewis, 2002; Ziguras, 2006; MacDonald, 2011). The Illawarra region is particularly striking in the Australian context. As noted, the region has transitioned, within a dominant neoliberal matrix, from its manufacturing and mining base, to an economy in which education, health care and public administration are important, along with retail and tourism/hospitality. As the region transitions, an examination of its complexity and dynamism are important, in order to gain a local understanding of how the global impacts and hegemonic nature of neoliberalism are changing and operating both at the industrial and post-industrial level. Youth are currently one of the most disadvantaged groups in the Illawarra region with respect to employment. The region's youth unemployment rate for example, has been consistently higher than state and national averages over the last few decades. These dimensions are shown in Table 1 and Figure 1. 
Table 1: Selected Australian Regional Youth Unemployment Rates December 2012

\begin{tabular}{|c|c|c|}
\hline Regional Locality & Unemployment Rate\% & $\begin{array}{c}\text { Youth Unemployment } \\
\text { Rate\% }\end{array}$ \\
\hline Illawarra & $\mathbf{8 . 8 \%}$ & $\mathbf{2 0 . 7 \%}$ \\
\hline Mid-North Coast & $6.8 \%$ & $17.8 \%$ \\
\hline Wide Bay-Burnett & $9.6 \%$ & $15.9 \%$ \\
\hline Northern Adelaide & $9.0 \%$ & $14.7 \%$ \\
\hline South Eastern Melbourne & $6.9 \%$ & $14.2 \%$ \\
\hline Fairfield-Liverpool & $7.1 \%$ & $13.9 \%$ \\
\hline Newcastle & $4.5 \%$ & $11.3 \%$ \\
\hline N.S.W & $5.1 \%$ & $11.5 \%$ \\
\hline Australia & $5.4 \%$ & $16 \%$ \\
\hline
\end{tabular}

\section{Source: DEEWR Small Area Labour Markets, December 2012, Australia}

For young people, employment opportunities have been particularly limited including entry level positions for the various cohorts of school leavers. In 1996, youth unemployment stood at $11.6 \%$ compared to a national rate of $9.2 \%$. In 2000 , the average unemployment rate for 20-24 year old males was 26 per cent approximately four times higher than the Sydney metropolitan average for this age group. For young people 15-19 years old, the unemployment rate was $32 \%$ whereas the Sydney statistical district was $13 \%$ while NSW was $16 \%$. More recently, the impacts of the global financial crisis have increased the levels of job losses amongst young people. Just before the economic crisis, the Australian youth unemployment rate for young people aged 15 to 24 years old was at its lowest since the 1970's. Between 2008 and 2009 however, the rate of unemployment among teenagers who were not in full-time education rose from $12.2 \%$ to $18.5 \%$ - one of the largest annual increases in 20 years. In December 2012, the youth unemployment for the Wollongong Statistical District (WSD) stood at 15.2\% (ABS, 2009; 2012). Wollongong and Shellharbour local government areas are among the three highest locations in New South Wales for youth unemployment. Some young people are facing a fourth generation of unemployment in their families (Australian Government, 2012: 16). 
Figure 1: Adult and Youth Unemployment Rates in the Illawarra Region September 1992-September 2012

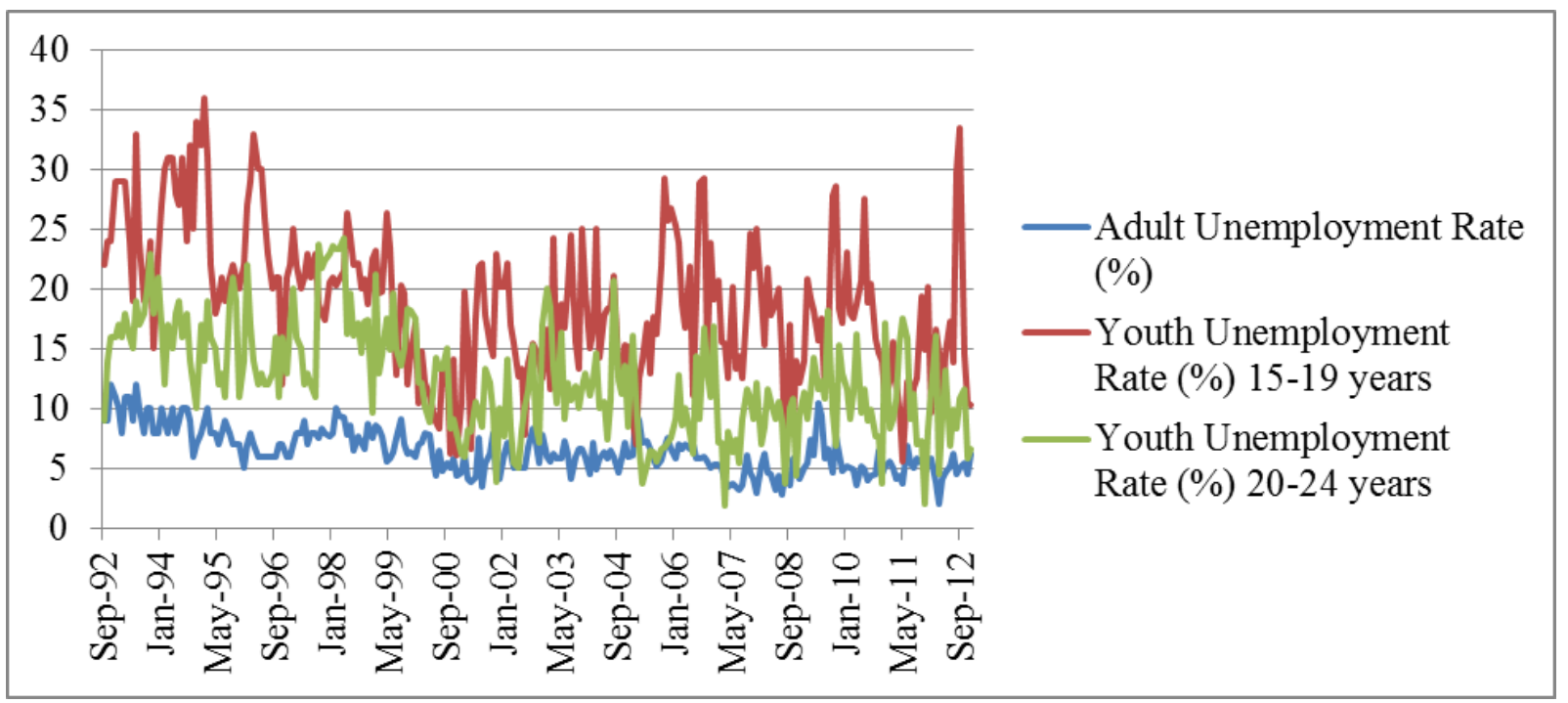

Source: ABS Labour Force Status by Region, September 2012, Australia

In the Illawarra, the retail sector accounts for almost half of teenage employment. Wage levels are low, particularly for sales workers (IRIS Research, 2008: 20). The higher end of the labour market has also experienced lackluster growth over the last two decades, increasing the concentration of young people in lower paying sections of the youth labour market. Indeed, many of the positions that employed young people, particularly first year apprenticeships, have declined. The region in this respect mirrors the configurations and trajectories of Australia with sales workers representing the highest proportion of employees without paid leave entitlements (ABS 2011). On the other hand, as the region's economy diversifies, service industries such as health care and social assistance, and education and training are playing a larger role and are generally becoming more substantial in the Wollongong Statistical District (WSD) than in N.S.W. The estimates of total employment indicate that healthcare and social assistance and the retail trade industries are only slightly behind manufacturing in contribution to the region's employment (IRIS Research, 2008: 18). Despite the growth of aged care employment, it is not an industry that attracts young people. Projects such as 'Young @ Heart', are designed to draw in and train disadvantaged job seekers under 35 years for careers in the industry (Australian Government, 2012: 17). The Green Jobs initiative already mentioned, which was designed by community activists to utilise national government stimulus package funding at the beginning of the Global Financial Crisis, has now been taken up as part of the Government's 2012-2014 regional employment strategy (Australian Government, 2012: 17). 


\section{Methods of the Study}

Despite the difficulties of job creation and the levels of youth under-employment and unemployment across the region, the nature of precarious work is difficult to ascertain from the official statistics. The Australian Bureau of Statistics (ABS) defines casual workers as those who do not have paid leave entitlements but this does not capture the growing numbers of young workers who are employed either part-time or full-time on casual employment contracts (ABS 2011). The actual numbers of casual young workers is also unclear owing to regional sampling issues and the probability of error but some estimates can be ascertained for part-time and full-time workers (employed temporarily) who accrue leave. With this in mind, the following sections of the article aim to provide a snapshot of precarious work amongst young people. The intention is not to provide generalizable patterns of precariousness amongst young people but to build a story of some of the experiences of the region's young people.

Qualitative interviews were conducted with thirty young people including men $(n=15)$ and women $(n=15)$ aged between 15-24 years old. Participants had a variety of employment statuses including employed, under-employed and unemployed although many were moving in and out of the labour market on a regular basis. The sample of young people was drawn from a pool of candidates from a local provider of employment assistance services for young people. The face to face unstructured interviews were conducted in various locations throughout the region. Each interview was recorded over a period lasting from 30 minutes to 2 hours. A University of Wollongong Human Research Ethics Committee set stringent guidelines relating to the welfare of young people and their privacy.

The interviews with some young people were quite challenging. During the course of them, it became clear that many of the young people were facing personal struggles with employment, under-employment and unemployment. Despite initial caution of the researcher, they became more relaxed as the interview proceeded and were generally forthcoming with their views. To draw out relevant themes, participants were asked to talk about their particular experiences of employment including their background, education and training, previous work experience, current experiences in finding work and experiences of work. For some young people, the process of an interview was a little overwhelming. Some participants needed encouragement to 'stick out' the interview when they became distracted or uninterested in the subject matter. Some young people walked out during the interview process but persevered with encouragement from their case manager. The interviews were fully transcribed then analysed through thematic coding based on the use of NVivo qualitative data analysis software.

\section{Young People's Experiences of Precarious Work in the Illawarra Region}

The section of the article explores notions of precariousness experienced by young people who are employed, under-employed and unemployed throughout the region. Understanding of the notion of precarious work was evident throughout the interviews: young people were generally aware that many of the jobs they were doing and searching for were insecure. While finding the right job that suited their particular personal and career aspirations was paramount, a number indicated that they would take just about any job available, regardless of pay and conditions.

'Choosing' the job

Although many young people were aware that many of the jobs they were undertaking were fraught with precarious conditions and pay, these conditions were 
accepted, because of a realisation of the overall lack of jobs and poor employment prospects. Others believed the jobs they were seeking matched their skills, experiences and abilities. Despite the precariousness of the labour market, young people tended to be quite deliberately selective of the sorts of jobs they wanted. Hannah, aged 15, expressed the view that some of her friends were 'picky', rejecting jobs with poor conditions and wages:

Hannah l've been looking for work for ages and everything around Wollongong has crappy pay and l've heard from me mates that some employers are nasty.

Interviewer: ...Can I ask you though what conditions you're expecting in your job search?

Hannah: I guess l'd like to get a job first (laughs) and then I don't mind if I'm casual to start but eventually l'd like a contract or be permanent. That's what I aspire to.

This young participant's assumption that employment commences casually before transitioning to either a contract or permanent arrangements reflected a deeply held belief about the labour market, reinforced by other participants who had a central conception of themselves as being discriminating in their search the right job and making careful choices about conditions. . Alex, aged 22, reflected this belief in the jobseeker as making a free and deliberate choice:

Interviewer: Is it important for young people to pick and choose the sorts of jobs they want particular the right conditions?

Alex: Absolutely, it's very important. I'm not doing a job I won't enjoy without reasonable conditions and pay. That's wasting my time and the employers' time. Friends of mine have taken different jobs and many of them have regretted taking them because they didn't enjoy them, the conditions weren't good and they didn't last in the job. That got a lot of my friends down and even upset if they lost their job.

Thus while young people were aware of the reality of precarious work as a significant aspect of their job search experiences, at the same time a number of held a simultaneous belief in the individual's right to accept only a desirable job and to reject any job whose conditions were not to their satisfaction or needs. Daniel, aged 20, commented:

I think that's just stupid actually - why accept a job just for the sake of it? Some jobs are ok and you can stick it out sometimes but if it's the wrong job, I don't reckon you should accept at all especially if the conditions are bad.

With strong understandings of precarious work, a number of young people had decided not to look for jobs in Wollongong but to travel 85 kilometres to Sydney for work. They believed that Sydney had a larger labour market, offering more choice and generally much better conditions than Wollongong. Young people with less training, who had generally been unemployed longer, were less inclined to be selective, although Jake, aged 16, was prepared to accept any job that arose in the Illawarra or Sydney whilst undertaking his apprenticeship.

Jake: I'll work in Wollongong or Sydney. I just wanna get on the band wagon and start work while I do my apprenticeship. 
Interviewer: Are you happy with the conditions of your apprenticeship?

Jake: Yeah, I guess so, I mean I'll earn good money in the future once I get a good job.

Young people who had completed or commenced higher levels of education such as Technical and Further Education (TAFE) or University were even more selective. Miriam, aged 24, was determined to get a job that would suit her individual requirements. She believed that because she had completed a diploma she would avoid work that had precarious conditions:

Miriam: I just want to make sure I get the right job for myself, with good pay and leave entitlements. That's really important to me.

Overall, the majority of interviewees did not see themselves as obliged to take any available job despite the temptation to move from unemployment into employment. Whilst recognising the nature and prevalence of precarious work, they still felt that somehow they were immune, and that it was their responsibility, and within their individual power, to improve the labour market by finding the good job that must be there, if only they could locate it. Despite awareness of the casualised and part-time nature of the region's youth labour market, some participants did not take account of whether available work was casual, part-time or full-time, temporary or permanent as a key job search consideration. They did not factor into their job search strategy a consideration of whether a particular casual job was either a path permanent employment, or a path to a 'dead end': most participants simply accepted as an article of faith that in the future the possibility of stable employment would become a reality (Gaston and Timcke 1999). Whilst some of the young people had confronted the paramount self-realisation that they were faced with a relatively uncertain future, others, despite the awareness of job uncertainty, were simply fixed in the determination (probably unrealistic) that by an act of individual will, they would eventually obtain the job they wanted. In this group, each lone individual, embarking into a sea of opportunity or uncertainty, was piloted by an inner sense of the ideal job.

Young people amongst this cohort appeared motivated to actively shape their particular circumstances. Female participants appeared strongly focused on obtaining the right skills for the job, and expected to continue upgrading their qualifications as a strategy for navigating the labour market, once employed. In answer to the question, "Do you have the adequate skill and education to attain this career?', typical comments were:

Keelee (aged 15): Not yet but will after TAFE and I except to gain further qualifications once l've got the job l'd like.

Hannah (aged 15): I have a Certificate III in Child Care and I expect to get further qualifications once l've found the right job.

On the other hand, some male participants felt comfortable about making irregular choices, taking each new job without hesitation.Alex, aged 22, had worked in a number of jobs casually before eventually accepting the job that he thought was right for his needs and career aspirations.

...l'm currently employed and I'm enjoying my job. I don't think it's a career job really, I mean, I've had a few casual jobs in retail and stuff before, for like three months and before that I was a barista for two years in three different cafés. 
Much of the research evidence indicates however that the young people tended to experience some form of unemployment regardless of the prospects of finding a job. This is likely to correlate with further unemployment in the future (Penman 2004: 50). If young people spend long out of the labour force, they can become 'at risk' of losing important work skills and the familiarity with technology in order to undertake their job (Hillman 2005: 23).

Many participants naively thought they would simply walk into a job, but found the reality to be otherwise:

Daniel (aged 22): I just thought I would find an okay job like a cleaner or something low skilled while I did my TAFE training. I found that there wasn't jobs around and had to wait until I finished my training. This was hard because I had to support myself.

Some young people then, expressed a strong desire to find work as soon as possible. Marks(2006: 45) argues that the sooner a young person finds a job the better the transition they will make to stable employment in the future. The hazards of unemployment among young people require a focus at the policy and program level, in helping secure employment as soon as possible, for their own well-being and also to avoid being 'becalmed' in education and training that may have no use to their future job prospects. Overall, despite the poor job prospects, most young people had a strong sense that they personally would secure a job that would meet their individual requirements Such high motivation suggests that young people are driven by a neoliberal ideology of the labour market, with little conceptualisation of limited employment prospects, and then wonder why this leads to undesirable employment outcomes, whereas a more nuanced understanding might result in better strategies or less internalisation of disappointment.

Getting the job and understanding its precariousness

Despite the length of time that many young people were out of work in the region, it was surprising that many interview participants found a job relatively quickly. Often however, this was only to lose it a short time later. Some lost their jobs through under-performance but others were bullied or discriminated against. Recounting these experiences was emotional for some participants and many felt unable and unwilling to discuss them at any length. The nature of the work they experienced however was less controversial and many were willing to discuss the sorts of jobs they had held and their various conditions. Jenny, aged 21, had worked in a local bakery as an assistant, and experienced poor conditions at work.

Jenny :I get up really early to go to work like $5 \mathrm{am}$ and it's flat-out until about $10 \mathrm{am}$. My pay isn't great and the owners are nice people but they're constantly under pressure to get the goods out. Overall, it's hard work but at the end of the day I don't feel rewarded very well either financially or in my personal career aspirations.

Interviewer: So, this job is a stepping stone for your future career. Is that right?

Jenny: Yes, but I hope my pay increases.

Interviewer: OK, if you don't mind me asking, does your job have holiday and sick leave and regular hours of work? 
Jenny: At this stage no because I'm casual but hopefully I will get those conditions soon.

Like several other young people, Jenny found the job bearable because of a belief that the prospects of better pay and leave entitlements were achievable. This belief is reflected in the youth transitions literature (Goodwin and O'Connor 2005; Wyn and Woodman 2006; Furling, Woodman and Wyn 2011) along with the notion that 'bad jobs' may be 'stepping stones' to better job prospects. As Masterman-Smith and Pocock (2008: 85) argue, however,

The stepping stone thesis is deeply embedded in our notions of Australia as a meritocratic society and the idea that we 'make' ourselves by moving up robust ladders of opportunity. The 'ladder of opportunity' out of low pay is a central rationalisation for the existence of low pay in a prosperous society, especially one that values fairness, like Australia. Few Australians would like to think that they inhabit a nation in which an individual's best efforts are insufficient to protect them from poverty or hardship. Those social conditions tend to be equated with poorer, less democratic nations.

The notion that their own job is different from others and will somehow provide a stepping stone can be seen in the words of Alicia, a 19 year old child care worker:

Participant: Basically, I work 8am-6pm five days a week. I'm happy to be working but it's hard after a while because childcare is a demanding job. The pay is average and the industry itself still needs accreditation and improvements in education and training. Other workers I speak to tell me they have it much harder with less pay and longer hours at other child care centres. They also have less opportunity for promotion and other benefits and they tend to burn out after a while.

Daniel, a 20 year old law student working casually in a supermarket to support his university degree, commented on the lack of prospects for co-workers:

Daniel: Well when I finish I expect to get a good job because I'm doing a law degree...I wouldn't like this job forever. I mean there's really no progression (maybe to store manager) but outside of that you wouldn't be able to buy a house or have descent pay to have a good life I reckon.

The feeling of going nowhere for many young people and the sense that the jobs are dead-ends rather than having promising futures has become the way in which many jobs in the contemporary labour market are now viewed. Despite this, young people persist in jobs that require long hours and poor conditions and pay, in the hope that the conditions will improve, or that the work will lead to better employment in the future. For many young people, financial circumstances drive their motivation to work. Many interview participants felt that there was no alternative and unemployment and receiving benefits was not an option even when there was no evident financial pressure. Aaron aged 23, expressed this feeling:,

Aaron: I still live with Mum and Dad but l'm expected to work and contribute to my family even though I don't have to pay rent and things like that.

The ideology of individual choice and personal responsibility, consonant with prevailing neoliberal norms, are experienced in the employment attitudes of young people. 


\section{Conclusion}

There is nothing out of the ordinary about the experiences reported here. Their very familiarity is precisely the point. Young people in the Illawarra region seek and accept precarious forms of work as a matter of course. Yet, the notion of precariousness remains elusive to them: this type of employment is accepted as a normal condition of life, preferable to unemployment. The ideology of individual choice and responsibility disguises the poor quality of employment for young people. In circumstances where '...the virtues of free trade, flexible labour and active individualism [have] become so commonplace in contemporary politics...that they hardly even warrant a comment in many quarters' (Peck and Tickell, 2002: 381), it is hard for young people to imagine any alternative but the ongoing individual search for the better job or stepping stone to greater security.

It was noted that the experiences recounted here reflect a fourth generation of precariousness in some families. The last major steel industry restructure was as recent as 2011. More research is needed, in both the Illawarra region and other areas, to ascertain the ongoing local impacts of economic crisis. In particular, political economic and sociological analysis is needed of regions undertaking restructuring projects under the aegis of neoliberal ideology. Regional studies are also important, given the difficulties of determining the actual numbers of precarious workers officially. For young people growing up and entering a regional labour market overshadowed by precarious employment, the broader individual and social impacts of such work is an important focus of a research agenda to understand youth cultures and broader youth transitions in education, training and work.

Earlier versions of this article were presented at the Australian and British Sociological Association Annual Conferences, London School of Economics and Political Science and University of Newcastle, Australia 2011 and the Researching Precarious Work Societies Workshop, Department of Sociology, Macquarie University, 2012.

\section{References}

ABS (Australian Bureau of Statistics) (2009) Labour Force Australia, December. Cat. no. 6202.0. Canberra ACT Australia: Australian Bureau of Statistics.

ABS (2011) Forms of Employment, Cat. no. 6359.0. Canberra ACT Australia: Australian Bureau of Statistics.

ABS (2012) Labour Force Australia, December. Cat. no. 6202.0. Canberra ACT Australia: Australian Bureau of Statistics.

Australian Government (2012) Regional Education, Skills and Jobs Plan: New South Wales - Illawarra 2012-2014. July. Canberra: The Office of Regional Education, Skills and Jobs.

Beer A, Clower T, Haughton G \& Maude A (2005) 'Neoliberalism and the institutions for regional development in Australia'. Geographical Research 43(1): 49-58.

Burrows S (2010a) 'Contesting the social impacts of neoliberalism: Economic recovery, unemployment and young people in the Illawarra region'. In G. Wrightson (ed.) The Aftermath of the Crisis. Incorporating the 12th Path to Full Employment Conference and the $17^{\text {th }}$ National Conference on Unemployment . Centre of Full Employment and Equity (CofFEE). Newcastle NSW Australia: University of Newcastle, pp. 21-34. 
Burrows S (2010b) 'Youth unemployment in the Illawarra Region'. Journal of Australian Political Economy 65:89-106.

Burrows S (2011/2012) 'Unemployment in the Illawarra Region: Understanding its Historical Trajectory and Legacy', Illawarra Unity: Journal of the Illawarra Branch of the Australian Society for the Study of Labour History, 11 (1): 51-66.

Carney T \& Ramia G (2002) From Rights to Management: Contract, New Public Management and Employment Services. London UK: Kluwer Law International.

Cheshire L \& Lawrence G (2005) 'Neoliberalism, individualisation and community: Regional restructuring in Australia'. Social Identities,11 (5): 435-445.

Considine M (2001) Enterprising States: The Public Management of Welfare to Work. New York: Cambridge University Press.

Cook B, Mitchell W, Quirk V. \& Watts M (2008) Creating Effective Local Labour Markets: A New Framework for Regional Employment Policy. Centre of Full Employment and Equity (COFfEE), University of Newcastle, Newcastle.

DEEWR [Department of Education, Employment and Workplace Relations] (2012) Small Area Labour Markets, December. Available: http://www.deewr.gov.au/employment/Imi/pages/salm.aspx[Accessed 23 April 2013].

Eardley T (2000) 'Working but poor? Low pay and poverty in Australia'. Economic and Labour Relations Review 11(2): 308-338.

Furling A, Woodman D \& Wyn J (2011) 'Changing times, changing perspectives: Reconciling "transition" and "cultural" perspectives on youth and young adulthood'. Journal of Sociology 47(4): 355-370.

Gamble A (2006) 'Two faces of neoliberalism'. In R. Robison (ed.) The Neoliberal Revolution: Forging the Market State. New York: Palgrave Macmillan.

Gaston N \& Timcke D (1999) 'Do casual workers find permanent full-time employment? Evidence from the Australian Youth Survey'. Economic Record 75 (4): 333-347.

Goodwin J \& O'Connor H (2005) 'Exploring complex transitions: Looking back at the "golden age" from school to work'. Sociology 39 (2): 201-220

Green Jobs Illawarra Action Plan (2009), A Report to the Honourable Nathan Rees, Premier of New South Wales from the Green Jobs Illawarra Project Steering Committee, Wollongong.

Harvey D (2005) A Brief History of Neoliberalism Oxford UK: Oxford University Press.

Hillman K (2005) Young People outside the Labour Force and Full-time Education: Activities and Profiles. LSAY Research Report No. 45. Melbourne Victoria Australia: Australian Council for Educational Research.

Gramsci A (1971) Selections from the Prison Notebooks of Antonio Gramsci. Q. Hoare \& G. Nowell Smith (transl. \& ed.) London UK: Lawrence \&Wishart.

Humphrys E \& Collerson J (2012/2013) 'Capital against capitalism: New research in Marxist political economy'. Journal of Australian Political Economy 70: 5-10.

IRIS Research (2008) How is our labour force changing?, Economic Report Issue 1. The University of Wollongong NSW Australia: IRIS Research.

IRIS Research (2013) The Illawarra region. The University of Wollongong NSW Australia: IRIS Research. Available: http://www.iris.org.au/index.pl?page=220 [accessed 20 June 2013].

Kalleberg AL (2000) 'Non-standard employment relations: Part-time, temporary and contract work'. Annual Review of Sociology 26: 341-365. 
Kalleberg AL (2009) 'Precarious work, insecure workers: Employment relations in transition', American Sociological Review 74 (1): 1-22.

Kelly D (1989) Technology, Work and Management: Workplace Industrial Relations in Steelmaking at Port Kembla Steelworks 1967-1987, MCom (Hons) Thesis, University of Wollongong.

Kelly R. \& Lewis P (2002) 'Neighbourhoods and youth employment outcomes in Melbourne' Australian Journal of Labour Economics 5 (1): 61-76.

Lewis P \& McLean B (1998) 'The youth labour market in Australia: A survey'. Australian Journal of Labour Economics 8 (3): 156-175.

MacDonald R (2011) 'Youth transitions, unemployment and underemployment'. Journal of Sociology 47 (4): 427-444.

Mangan J and Guest J (1983) The Effects of the Downturn in the Steel Industry within the Wollongong Statistical District, Wollongong: IRIS Research.

Marks G (2006) The Transition to Full-time Work of Young People Who Do Not Go to University. LSAY Research Report No. 49. Melbourne Victoria Australia: Australian Council for Educational Research.

Masterman-Smith H. \& Pocock B (2008) Living Low Paid: The Dark Side of Prosperous Australia, Sydney NSW Australia: Allen and Unwin.

McKay S , Jefferys S, Paraksevopoulou A \& Keles J (2012) Study on Precarious Work and Social Rights. Report prepared for the European Commission, Working Lives Research Institute. London UK: Faculty of Social Sciences and Humanities, London Metropolitan University.

Mylett T (2003) The intensification of labour market polarisation in metals manufacturing in Australia in the 1900s. Doctor of Philosophy in the School of Management, Marketing and Employment Relations. Wollongong NSW Australia: University of Wollongong. Available: http://ro.uow.edu.au/theses/2034/.

Peck J \& Tickell A (2002) 'Neoliberalising space'. Antipode: A Radical Journal of Geography 34 (3): 380-404.

Penman R (2004) What do we Know about the Experiences of Australian Youth? Melbourne Victoria Australia: Australian Council for Educational Research.

Pocock B (2003) The Work/Life Collision: What Work is doing to Australians and What to Do about it. Annandale NSW Australia: Federation Press.

Quinlan M (2012) 'The "pre-invention" of precarious employment: The changing world of work in context', Economic and Labour Relations Review 23(4): 3-24.

Rafferty M \& Yu S (2010) Shifting Risk - Work and Working Life in Australia, Workplace Research Centre, University of Sydney.

Rittau, Y. (2006) Regional Labour Councils and Local Government Employment Generation: The South Coast Labour Council 1981-1996. PhD thesis. Sydney, NSW, Australia: The University of Sydney.

Robison R (2006) 'Neoliberalism and the market state: What is the ideal shell?' In R. Robison (ed.) The Neoliberal Revolution: Forging the Market State; New York: Palgrave Macmillan, pp. 3-19.

Schultz J (1985) Steel City Blues: The Human Cost of Industrial Crisis. Ringwood, Victoria: Penguin Books.

Southall N (2008) 'The WOW Factor: Wollongong's Unemployed and the Dispossession of Class and History, Illawarra Unity - Journal of the Illawarra Branch of the Australian Society for the Study of Labour History 8 (1): 69-79.

Standing, G (2011) The Precariat: The New Dangerous Class. London UK: Bloomsbury Academic. 
Stilwell F (2000) Changing Track: A New Political Economic Direction for Australia. Annandale NSW Australia: Pluto Press.

Van Wanrooy B, Wright S, Buchanan J, Baldwin S \& Wilson S (2009) Australia at Work: In a Changing World. Sydney NSW Australia: Workplace Research Centre, University of Sydney.

Vosko L (2000) Temporary Work: the Gendered Rise of a Precarious Employment Relationship. Toronto Canada: University of Toronto Press.

Vosko L (2006) Precarious Employment: Understanding Labour Market Insecurity in Canada. Montreal Canada: McGill-Queens University Press.

Watson I, Buchanan, J, Campbell I \& Briggs C (2003) Fragmented Futures: New Challenges in Working Life. Sydney NSW Australia: Federation Press.

Wooden M (1996) 'The youth labour market: Characteristics and trends', Australian Bulletin of Labour 22(2): 137-160.

Wyn J \& Woodman, D (2006) 'Generation, youth and social change in Australia', Journal of Youth Studies 9(5): 495-514.

Ziguras S (2006) 'Labour market transitions and risks of exclusion'. Australian Bulletin of Labour 32 (3): 203-226.

\section{Author Biography}

Scott Burrows teaches and researches at the University of Wollongong. Email: sburrows@uow.edu.au 